\title{
Regional human capital development management in the process of globalization
}

\author{
Irina Ershova ${ }^{1, *}$, Iuliia Solodiankina ${ }^{1}$ \\ ${ }^{1}$ Department of Finance and Credit, Southwest State University, Kursk, Russia
}

\begin{abstract}
.
Research background: Active development of information technology and globalization have made the digital economy an integral part of global and national economic systems. A key factor in the success of globalization processes is the availability of highly qualified personnel in sufficient volumes and relevant jobs, as well as a training system for specialists with certain competencies for the development and implementation of digital technologies.

Purpose of the article: development of guidelines for innovative management of regional human capital formation in the global economy. To achieve this goal, the following tasks were solved: to identify the impact of quality education on the development of human capital; to evaluate the effectiveness of higher education institutions as one of the fundamental factors in the formation of human capital in a region in the process of globalization; to develop a methodology for the formation and improvement of human capital by modernizing the distance education system.

Methods: dialectic, abstraction, analysis, induction, modeling, as well as statistical methods, comparison method.

Findings \& Value added: As a result of this study, an idea has been formed on the impact of quality education on the development of human capital; the analysis of the activities of higher education institutions as one of the factors in the formation and development of human capital in the region; a methodology has been developed for the formation and improvement of human capital by modernizing the distance education system.
\end{abstract}

Keywords: human capital; globalization; higher education

JEL Classification: $A 11 ; A 14 ; B 16$

\footnotetext{
*Corresponding author: ershovairgen@yandex.ru
} 


\section{Features of the impact of quality education on the formation and development of human capital}

The transition to a digital economy is fundamentally changing the labor market: along with the spread of information technology in all spheres of life, digital skills are becoming critically important from the point of view of employers. A massive transformation in talent requirements is expected, as many operations that have not been affected by previous waves of digital adoption may be automated in the near future.

Increasing the literacy of the population contributes not only to the development of the economy, but also to maintaining public order and living standards. Currently, there is insufficient funding for higher professional education. Part of the population is forced to take loans for higher professional education. In addition, there is uncertainty about the ability to benefit from the education received.

Students in most professions are not confident that they will work in their specialty. This suggests that despite the increase in the number of people receiving higher professional education, the level of professional staff is declining, since only $43 \%$ of students studying natural sciences intend to work in their specialty, and the remaining $57 \%$ will take jobs that do not correspond to their education. This trend of uncertainty about the future results in an overestimated indicator in reports and a decrease in the number of professionals in the workplace. Modern society is inconceivable without the proper development of specialists in the field of information technology, but only 47.3 students studying mathematics and programming are going to work in their specialty $[1,2]$.

In order to come out on top in the world among information technologies, it is necessary to increase the number of budget places with subsequent employment for students of this specialty. Subsequently, each such student will pay off several times if he takes part in the development of high-quality software. The development of technical potential, educational activities, natural sciences and humanities is impossible without the preparation of highquality qualified and motivated personnel. To date, the uncertainty with employment has led to the fact that only about $50 \%$ of students studying in the above areas assume the opportunity to get a job in their specialty (Table 1).

Table 1 - Plans of students for employment in the specialty,\%

\begin{tabular}{|c|c|c|c|c|c|c|}
\hline & Total & $\begin{array}{c}\text { Social } \\
\text { sciences }\end{array}$ & $\begin{array}{c}\text { Technical } \\
\text { sciences }\end{array}$ & Medicine & $\begin{array}{c}\text { Humanitie, } \\
\text { cultural } \\
\text { studies and } \\
\text { pedagogy }\end{array}$ & $\begin{array}{c}\text { Other } \\
\text { specialties }\end{array}$ \\
\hline Yes & 51.7 & 47.3 & 48.9 & 70.2 & 59.3 & 46.5 \\
\hline Maybe yes & 38.1 & 40.5 & 40.7 & 23.4 & 32.8 & 42.6 \\
\hline Maybe not & 6.2 & 7.1 & 6.5 & 3.8 & 5.6 & 6.1 \\
\hline No & 2.7 & 4.1 & 2.4 & 1.1 & 1.7 & 2 \\
\hline $\begin{array}{c}\text { I'm not } \\
\text { going to }\end{array}$ & 1.3 & 1 & 1 & 1.5 & 0.7 & 2.1 \\
\hline
\end{tabular}

According to students, for successful employment they need the following: practical knowledge and skills (54\%), basic theoretical knowledge (41\%), the ability to solve problems arising in the course of work $(33 \%)$, etc. Students noted an acute lack of knowledge and skills in the following areas: practical knowledge and skills (39\%), knowledge of a foreign language (33.5\%), business communication skills $(21 \%)$. It should 
be noted that $56 \%$ of students feel the need for additional education after graduation (Table 2).

Table 2 - The ratio of skills required, according to students, for successful employment, and skills that students lack

\begin{tabular}{|c|c|c|}
\hline Skills & $\begin{array}{c}\text { Skill required for } \\
\text { employment, } \%\end{array}$ & $\begin{array}{c}\text { Skill that } \\
\text { students lack, } \%\end{array}$ \\
\hline Practical specific knowledge and skills & 54,1 & 39,6 \\
\hline Basic theoretical knowledge & 40,9 & 18,7 \\
\hline $\begin{array}{c}\text { Ability to solve problems arising in the } \\
\text { course of work }\end{array}$ & 33,7 & 13,1 \\
\hline analytical skills, data analysis & 30,1 & 17,9 \\
\hline Learning ability & 28,7 & 15,9 \\
\hline Ability to work with modern equipment & 28,1 & 13,3 \\
\hline Ability to work independently & 25,3 & 5,7 \\
\hline Computer skills & 23,7 & 21,3 \\
\hline Business communication skills & 22,7 & 11,3 \\
\hline Customer Interaction Ability & 22,1 & 33,5 \\
\hline Knowledge of a foreign language & 20 & 15,8 \\
\hline Organizational skills & 19,3 & 5,6 \\
\hline Ability to collaborate with colleagues & 19,3 & 13 \\
\hline Compliance with labor discipline & 18,6 & 11 \\
\hline Ability to show initiative & 20,1 \\
\hline
\end{tabular}

\section{Evaluation of the effectiveness of higher education institutions as one of the fundamental factors in the formation of human capital in the region in the process of globalization}

Currently, higher education institutions can achieve a significant increase in competitiveness not only by increasing the role assigned to the dynamic capabilities of the university's development, but also by the continuous development of personnel throughout their lives, which leads to a constant build-up of competence.

Assessment of the effectiveness of the activities of universities consists of 6 different indicators: educational, research, international, financial and economic activities, salaries of the teaching staff and employment. All categories of indicators have median values that reflect the effectiveness of the university in a particular area $[3,4,5]$. 
The section "Educational activities" includes indicators that allow assessing the average and average USE score of students, bachelors and specialists in various full-time training programs, the number of undergraduates, as well as the proportion of graduate students per 100 students. In addition, this indicator reflects the number of employees with academic degrees of candidate and doctor of science.

The indicator of research activity is calculated on the basis of the number of publications and citations of scientific works in the Russian and international systems RSCI, Web of Science / Scopus, the volume of R\&D per one faculty member and other indicators $[6-8,9]$.

International activities include indicators characterizing the number of foreign students.

The indicators of financial and economic activity are the income of the university, received per one scientific and pedagogical worker.

An innovation in the monitoring of 2014 is the section "Salaries of teaching staff", which allows you to assess the level of salaries of the teaching staff of the university.

The group of indicators "Employment" characterizes the number of employed and unemployed among university graduates.

In order to compare the criteria by importance, it is necessary to use the method of paired comparisons, which is a method of obtaining initial data, a method of a kind of survey of respondents. To reflect the objective results, a survey was conducted among independent experts in the field of education: heads of universities and teaching staff, heads of state bodies, as well as heads of enterprises and organizations. Based on the survey data, the average values of each criterion for assessing the effectiveness of the university's activities were calculated (Table 3).

Table 3 - Criteria for assessing the effectiveness of the university

\begin{tabular}{|c|c|c|c|}
\hline Criterion & Mean & Criterion & Mean \\
\hline 1. Educational activities - (O) & 9.7 & $\begin{array}{c}\text { 4. Financial and economic } \\
\text { activity - (F) }\end{array}$ & 5.5 \\
\hline 2. Research activities - (N) & 9.4 & 5. Salary of PPP - () & 8.6 \\
\hline 3. International activity - (M) & 6.3 & 6. Employment - (T) & 7.6 \\
\hline
\end{tabular}

Table 4 presents a matrix of binary relations, where $\mathrm{Si}$ is the sum of features, Wi is the weight value of the indicator in the general population.

Table 4 - Matrix of binary relations of the considered criteria

\begin{tabular}{|c|c|c|c|c|c|c|c|c|c|}
\hline & Signs & $\mathrm{O}$ & $\mathrm{H}$ & $\mathrm{M}$ & $\Phi$ & 3 & $\mathrm{~T}$ & $\mathrm{~S}_{\mathrm{i}}$ & $\mathrm{W}_{\mathrm{i}}$ \\
\cline { 2 - 10 } $\mathrm{B}_{\mathrm{ij}}$ & $\mathrm{O}$ & 1 & 2 & 2 & 2 & 2 & 2 & 11 & 0.31 \\
\cline { 2 - 10 } & $\mathrm{N}$ & 0 & 1 & 2 & 2 & 2 & 2 & 9 & 0.25 \\
\cline { 2 - 10 } $\mathrm{M}$ & 0 & 0 & 1 & 2 & 0 & 0 & 3 & 0.08 \\
\hline $\mathrm{F}$ & 0 & 0 & 0 & 1 & 0 & 0 & 1 & 0.03 \\
\hline
\end{tabular}




\begin{tabular}{|c|c|c|c|c|c|c|c|c|c|} 
& $\mathrm{Z}$ & 0 & 0 & 2 & 2 & 1 & 2 & 7 & 0.19 \\
\hline $\mathrm{T}$ & 0 & 0 & 2 & 2 & 0 & 1 & 5 & 0.14 \\
\hline \multicolumn{8}{r|}{ Total : } & 36 & 1.00 \\
\hline
\end{tabular}

Based on the results obtained (Table 4), it was found that the integral indicator of the effectiveness of activities is influenced by such criteria as educational and research activities.

In order to assess the level of efficiency of universities in the Central Federal District, a sample of 69 educational institutions was carried out and a comprehensive assessment of the effectiveness of activities was carried out.

$$
K_{e f}=\sum_{i=1}^{n} X_{i} \times w_{l}
$$

where $\mathrm{X}_{\mathrm{i}}$ is an indicator of the university's performance, $\mathrm{w}_{\mathrm{i}}$ is the weighted value of the indicator in the general population.

The analysis showed that in each region there are several leading universities, which are superior to others in most indicators. This trend is observed throughout the Central Federal District, as well as in the capital of the Russian Federation - Moscow. Given the fact that a merger of universities can be carried out at the regional level, taking into account performance indicators becomes a decisive factor in making such a decision.

\section{Institutional development of human capital by improving the system of distance education}

The world education market increases its volume every year. According to Global Market Insights forecasts, by 2023 the share of online education should surpass the $\$ 240$ billion mark. USA. Average annual volume growth is over $5 \%$ per year. There is an opinion that the average annual growth is $17 \%$, since in addition to officially registered educational online projects, there are shadow projects.

The United States is the largest and most mature market for online education. This affects the slowdown in growth, amounting to $4-4.4 \%$ annually. Southeast Asia is the second largest online education region. The main market volume is occupied by China and India, with an annual growth rate of over 17\% [10-14].

Eastern Europe lags far behind Western Europe. The main driver of the market is Russia with a $20-25 \%$ growth excluding the unregistered shadow online educational sector.

According to Business Insider estimates, in educational centers in the future, the teacher will be replaced by artificial intelligence that can flexibly adapt to the inclinations, capabilities and goals of students. It is assumed that by 2030 an educational company may become the largest business on the Internet.

The highest growth rates are for organizations that create and sell educational solutions created on the basis of simulation of game mechanics of real processes. Until 2021 inclusive, the growth rate of such companies will be about $22 \%$. The most attractive educational startups for investors are online solutions for preparing for standardized exams and foreign languages.

Of particular demand among users are programs built on the principle of asynchronous learning, where the student independently determines the schedule, routine and intensity of classes, regardless of the teacher [15-20]. 
The most promising areas in the future will be the segments of corporate education, school and preschool education, tutoring and the study of foreign languages. According to industry research, there is an increase in the share of the private sector in various educational areas. In 2014, $28 \%$ of US students were enrolled in non-governmental educational institutions, an increase of $2.4 \%$ compared to 2013. In 2015, the United States had 18.6 million students in tertiary education, $29 \%$ of which fully or partly trained online. Online education followed by a state diploma is offered by a fairly large number of American universities and colleges. About $80 \%$ of US universities that provide educational services online outsource the maintenance and development of their courses. According to Technavio, the online tertiary education market will show an annual growth rate of $20 \%$ through 2021.

The share of online education in Russia by 2021 may amount to $2.6 \%$, which is significantly more than in 2016. It should be noted that the share of private business in the educational services market will decline, and the total market size may reach 2 trillion. rub.

In Russia, higher professional education is divided into three main groups: bachelor's, specialty and master's degrees. According to forecasts based on Rosstat demographic data, the number of students enrolled in the master's program in the period from 2017 to 2021 is is increasing, and the number of students enrolled in undergraduate and specialty studies is decreasing. The audience of higher professional education in the period from 2017 to 2021 is shown in Figure 6.

Despite the emerging market for online education, it is attracting interest from investors. In most cases, investment takes place at the expense of a Russian investor. The risks on the part of the investor are quite justified, since the presence of high competition in this industry is compensated by the high growth rates of demand for educational services, as well as the growth of the average check. In the case of a correctly chosen product for investment, it becomes possible to quickly return the invested funds and come out in profit. The most common are investments up to 1 million rubles.

The prospect of getting an education without visiting educational institutions is now becoming a reality. This is confirmed by millions of investments in the development of this industry. Such giants as Microsoft, Google, Apple, Facebook, Yandex and others have repeatedly proved the feasibility of their investment projects. Today, their gaze is focused not only on the IT sphere, but also on online education, which gives reason to consider this direction as promising and effective.

\section{Results}

As a result of the dissertation research, we made the following conclusions:

1. The main directions of human capital development in the era of globalization of the digital economy are the collection, storage and analysis of data on the necessary training and qualifications of university students. In addition, it becomes obvious the need to create a system based on the use of artificial intelligence, the purpose of which will be to study and analyze open statistical data on unemployment, the number of vacant jobs, the most demanded specialties and build a development model for future graduates of educational institutions with a forecast for 10-15 years. forward. This approach will allow you to quickly change the number of budget places for various specialties, thereby stimulating the correction of the number of graduates in each specific industry.

2. The development of human capital is a complex system of interconnections between various technological areas. So, for example, to forecast and stimulate the development of specialists, it is necessary to conduct an analysis using data processing methods. Subsequently, future specialists will need a qualified teaching staff that must meet modern requirements and actively use information technology. Universal digitalization has led to 
the spread of information technology in all spheres of human life, which is natural in the era of development of the digital economy.

3. The impact of digitalization on the country's economy can hardly be overestimated, since more and more positive changes in GDP growth are observed under its influence. This indicates the need for additional investment in the digital sphere of production. Despite the existing fears about a decrease in the demand for human capital as a factor in economic development, one should take into account the current replacement of specialists in some professions by others. So, without the development of specialists in the field of information technology, the further development of the digital economy is impossible.

4. The development of human capital is impossible without a qualitative modernization of the educational process, as well as the use of innovative technologies for teaching students. Lack of the proper level of training replaces the pace of human capital development. In the era of digitalization of the economy, constant change and improvement of educational programs is necessary. There is an urgent need to apply the case model of education. In this case, it is unacceptable to use existing training models. Only the modernization of the educational sphere will allow the formation of high-quality human capital capable of meeting the needs and requirements of the digital economy.

5. The analysis of the activities of higher educational institutions has shown the need to modernize educational processes in almost every region of the Central Federal District. The development of high-quality human capital is impossible without appropriate education. Only with the use of new approaches to the construction of the educational process is it possible to achieve significant changes in the development of the region. Investments in educational institutions should be taken seriously, since they are the fundamental factor influencing the formation and development of human capital. With the constant development of the digital economy, this issue is becoming more and more relevant. Denial of the existing problem in the process of training qualified personnel can lead to a slowdown in the pace of economic development.

6. Development and improvement of the distance education system allows increasing the competence of professional personnel. At present, the rates of information deactualization are quite high and the classical educational model is unable to match them. The employer is interested in professional and competent employees who have information that is relevant and necessary to fulfill their professional duties. It is possible to achieve rapid improvement of the qualifications of employees only by constantly raising their professional level. It is possible to do this without interrupting work using the distance education system, which will become more and more in demand over time.

\section{References}

1. Chernyak, A. Yu. (2010). Development laws for business systems Automation and Remote Control,71(10), 2239-2246.

2. Ershova E., Karakulin A., Ershova I., Okunkova E. (2019). Innovative management methods of training of personnel in the regional mining and processing plant. In KS. Soliman (Eds.), Proceedings of the 33rd International Business Information Management Association Conference, IBIMA 2019: Education Excellence and Innovation Management through Vision 2020 (pp. 7313-7318). Norristown: International Business Information Management Association - IBIMA.

3. Gurman V., Baturin, V. (2009). Ecological-economic model of the region: Information technology, forecasting and optimal control. Mathematical Modelling of Natural Phenomena, 4(5), 144-157. 
4. Jalal, A.Q., Essa Allalaq, H.A., Shinkevich, A.I., Kudryavtseva, S.S., Ershova, I.G. (2019). Assessment of the efficiency of energy and resource-saving technologies in open innovation and production systems. International Journal of Energy Economics and Policy. 9(5), 289-296.

5. Kritkova, S., Strielkowski, W. (2015). Economic and Business Aspects of Russian Energy Market: Development of Combined Heat and Power Technologies. Transformations in Business \& Economics, 14(1), 251-267.

6. Obukhova, A., Merzlyakova, E., Ershova, I., Karakulina, K. (2020). Introduction of digital technologies in the enterprise. E3S Web of Conferences. C. 04004.

7. Rostov, I. D., Rostov, V. I., Rudykh, N. I., Dmitrieva, E. V., Golik, A. V. (2014). Components of information support of marine activity and nature use in the Far East region of Russia. Oceanology, 54(3), 392-394.

8. Shinkevich, A.I., Kudryavtseva, S.S., Ershova, I.G. (2020). Modelling of energy efficiency factors of petrochemical industry. International Journal of Energy Economics and Policy. 10(3), 465-470.

9. Smith, P. B., Torre,s C., Leong, Ch.H., Budhwar, P., Achoui, M., Lebedeva, N. (2012). Are indigenous approaches to achieving influence in business organizations distinctive? A comparative study of guanxi, wasta, jeitinho, svyazi and pulling strings International Journal of Human Resource Management, 23(2), 333-348.

10. Vertakova, Yu. V., Polozhentseva, Yu. S., Plotnikov, V. A. (2015). Methods of detecting imbalances in the structure and dynamics of socio-economic system. International multidisciplinary scientific conference of social sciences and arts SGEM 2015. Conference proceedings: Political sciences, law, finance, economics and tourism. Volume II: Finance, economics and tourism (pp. 821-828). Sofia: Stef 92 Technology.

11. Zaikanov, V. G., Minakova, T. B., Buldakova, E. V. (2015). Principles of GIS support of geoenvironmental mapping at a regional level. Water Resources, 42(7), 970-974.

12. Zhuplev, A., Shein, V. (2008). Emerging issues and trends in business and management career development under the market transformation in Russia. European Journal of International Management, 2(1), 89-106.

13. Kharchenko, E., Garbuz, I. (2016). Mechanisms Of National Economy And Its Regions Adaptation To The Conditions Of Integration To The World Economy. Economic Annals - XXI, 157(3-4), 28-31.

14. Kolmykova, T., Telizenko, A., Lukianykhin, V. (2013). Problems of modernization and development priorities for industrial complex. Problems and Perspectives in Management, 11. 28-34.

15. Kolmykova, T.S., Emelyanov, S.G., Merzlyakova, E.A. (2017). Research Of Innovative Potential Of The Region. Journal of Applied Engineering Science, 15(3), 276-279.

16. Kolmykova, T.S., Merzlyakova, E.A., Bredikhin, V.V., Tolstykh, T.O., Ovchinnikova, O.P. (2018). Problems Of Formation Of Perspective Growth Points Of High-Tech Productions. Advances in Intelligent Systems and Computing, 622, 469-475.

17. Kurbanov, A., Gurieva, L.K., Novoselov, S.N., Gorkusha, O.A., Novoselova, N.N., Kovalenko, A.A. (2016). Features Sub-Regional localities in the Structural-Level organization of the economic system. International Review of Management and Marketing, 6(1), 287-292.

18. Androsova, I., Simonenko, E. (2016). Innovative approach to strategic management of machine-building enterprises. Economic Annals-XXI, 157(3-4), 94-96. 
19. Anisimov, A.Y., Zhaglovskaya, A.V., Kudra, A.A., Obukhova, A.S., Aleksakhina, Y.V. (2017). Strategic Approach To Forming A Human Resource Management System In The Organization. International Journal of Economic Perspectives, 11(2), 442-448.

20. Belyaeva, E., Svetovtseva, T. (2016). Main Trends Of Factoring Market Development At Present Economic Conditions. Economic Annals-XXI, 157(3-4), 65-67. 